\title{
ON INTERNAL RECONSTRUCTION, MORPHOLOGICAL RESTRUCTURATION AND NOMINAL CLASSES IN MANCHU*
}

\author{
JoSÉ ANDRÉS ALONSO DE LA FUENTE \\ Universitat Autònoma de Barcelona \\ Departament de Ciències de l'Antiguitat i de l'Edat Mitjana \\ Àrea de Lingüística Indoeuropea \\ 08193 Barcelona, Spain \\ e-mail: jose.andres25@gmail.com
}

Manchu words like giranggi 'bone' or senggi 'blood' are traditionally classified as part of a nominal class system inherited from the Proto-Tungusic parent language. This nominal class system has obscure origins and it is unproductive in the historical languages (Manchu included). Manchu giranggi and senggi contain the class suffix $+n g g i$ which in historical terms cannot be easily reconciled with the so-called "collective" suffixes $+k s a$ and $+k t a$ in Core Tungusic languages. In this contribution we argue that the class suffix $+n g g i$ is the result of the reanalysis $* \ldots \mathrm{V} / \mathrm{n}+\mathrm{g} . \mathrm{i} \Rightarrow \ldots V+n g g i$ whereby nasal nouns are reinterpreted as vowel nouns. Common Tungusic "collectives" *+kta and ${ }^{*}+\mathrm{ksa}$ are secondary formations that were created after Manchu had branched off. The general assumption is made that Manchuric (a.k.a. Jurchenic) serves best to improve our understanding of the prehistory of the Tungusic languages when it is seen as the conservative member of the family instead of the innovative one as usual.

Key words: Tungusic languages, etymology, analogical reanalysis, derivational morphology, noun class suffix, collectives and plurals.

\section{The Problem}

In his comparative grammar, Benzing (1956, pp. 68-72, §§78-81, esp. $\S 79[\mathrm{c}])$ suggested that Manchu words like giranggi 'bone' and senggi 'blood' are related to Literary Ewenki giramna 'skeleton' and sääksä 'blood' via *gïram-sä and *silä-g-sä, respectively. Benzing referred to the suffixal complexes $*+\mathrm{g}$-sa, and others like $*+\mathrm{g}$-ta,

* This paper was written thanks to a Juan de la Cierva Postdoctoral Fellowship from the Spanish Ministerio de Ciencia e Innovación (Ref. IJCI-2014-19343). I would like to thank the anonymous reviewers and Tomasz Majtczak (Jagiellonian University, Cracow) for their insightful comments on the paper. Any remaining errors are, of course, my own responsibility. 
as "collectives" ("Kollektivsuffixe"), but we will refer to them as "noun class" suffixes. ${ }^{1}$ From a semantic viewpoint, *-g-sA seems to specify masses of uncountable materials, whereas *-g-tA individualises single members of groups of countable objects. They can be found in attested across Core Tungusic languages as $+k s a$ and $+k t a$, etc., obviously with assimilation of $/ \mathrm{g} /$ to $/ \mathrm{k} /$ after $/ \mathrm{s} /$ (see Benzing's * säksä and *siläksä in $\S 40[\mathrm{c}]$ showing that *gïram-sä and *silä-g-sä were try-outs of internal reconstruction). The evolution of the formative *+ksa in Manchu, however, has eluded specialists for quite a long time. The opaqueness of the phonetic change leading from ${ }^{*}+$ g.sa to $+n g g i$ seems so abstruse that Benzing himself doubted it (1956, p. 29, $\S \S 40[\mathrm{~d}]$, cf. 51[c] *-ns- > +nggi +ha?).

Curiously enough, the salience of this comparison has gone unnoticed. It is even more remarkable if we take into account that noun class suffixes have been the object of previous research: Cincius (1946) put forward the idea that the suffixal complex $*+$ kta resulted from the grammaticalisation of the adverb kät( $\ddot{a})$ 'very, many, much'. Sunik (1982, pp. 21-24) claimed that the same formative is originally a suffixal complex made of the emphatic-diminutive $*+\mathrm{kaa}(\mathrm{n})$ and the plural(iser) $*+$ ta. Boldyrev (1987, pp. 83-108), who offers the most extensive research to date, correctly traced $*+$ kta and $*+$ ksa back to $*+$ gita and $*+$ gisa. However, he identified the component *gi with the causative and, seemingly, accepted the awkwardness of the Core Tungusic vs. Manchu comparison without reservations. Unfortunately, there is nothing to recommend in any of these proposals. They can be rejected out of hand on both phonetic and semantic grounds. More importantly, they do not take into consideration Manchu facts and, therefore, do not improve on our knowledge of the prehistory of Tungusic. ${ }^{2}$

The most recent discussion is that of Janhunen (1996, pp. 213-216, 1999, pp. 698-700). He mentions the striking and well known (see, i.a., Cincius 1977, pp. $42-$ 44, 47-48) formal and semantic similarities between (Common) Tungusic noun class suffixes and Mongolic ${ }^{*}+\mathrm{s} . \mathrm{u} / \mathrm{n}$ and $*+\mathrm{d} . \mathrm{u} / \mathrm{n}$, and presents a very explicit, comparative table which is reproduced below verbatim for the sake of illustration.

${ }^{1}$ Generally speaking, noun classes are defined in terms of agreement patterns (nominal or verbal). Since noun class does not require any special agreement rule in Tungusic, it may be argued that these languages do not posses proper "noun classes". Most authors consider that formal expression via derivation or semantics alone cannot be used to establish the existence of noun classes (see, i.a., Corbett 2007, p. 243: "[t]he presence of markers on the nouns, as prefixes or suffixes, does not of itself indicate that a language has genders (or noun classes); if we accepted this type of evidence, then we could equally claim that English had a gender comprising all nouns ending in -tion)". Notwithstanding this, we will keep the use of "noun class" as this term has gained some acceptance among linguists specialising in Tungusic and Mongolic (see, i.a., Vietze 1969: "Nominalklassen").

${ }^{2}$ The Pro-Altaicist literature on the topic is not extensive (Ramstedt 1952, p. 140 [iterative $-k t a$ ], pp. 213-214 [noun class suffix $+k s a$ ] sums it up, and remains valid until today). Unfortunately, this literature has zero value when it comes to shed some light on the intricacies of the Tungusic data under discussion, therefore, it will not be addressed in this paper. 


\section{Table 1. Nominal class correspondence between Mongolic, Tungusic and Manchu}

\begin{tabular}{|c|c|c|c|}
\hline & Mongolic & Tungusic & Manchu \\
\hline \multirow[t]{2}{*}{ I } & $*_{\text {si-d. }} / \mathrm{n}$ & *xüi-g-te & $>$ wei-he \\
\hline & $*(\mathrm{x}) \mathrm{o}-\mathrm{d} \cdot \mathrm{u} / \mathrm{n}$ & *xoosï-g-ta & $>u s i-h a$ \\
\hline \multirow[t]{5}{*}{ II } & *cï-s.u/n & ${ }^{*}$ se-g-se & se-ng.gi \\
\hline & *to-s.u/n & *ximö-g-se & (n)ime-ng.gi \\
\hline & $*^{c}$ ca-s.u/n & ${ }^{*}$ xïma.n-sa & nima-ng.gi \\
\hline & [not relevant] & *sile-g-se & sile-ng.gi \\
\hline & *ya-s.u/n & *gïra.m-sa & gira-ng.gi \\
\hline \multirow[t]{2}{*}{ III } & *pü-s.ü/n & *ñööri-g-te & [not relevant] \\
\hline & *kimu-s.u/n & *usï-g-ta & $>$ wasi-ha \\
\hline
\end{tabular}

Janhunen does not suggest any solution in regard to the Core Tungusic vs. Manchu comparison, but acknowledges the confusing sound change that operates in Manchu: "[...] we do not know why Manchu replaces the suffix *-C-sA with -nggi" (1996, p. $210)$ or "[...] for reasons yet to be clarified, [Manchu] regularly replaces the ProtoTungusic class suffix $*_{-} C-s A$ with -nggi" $(1999$, p. 700$)$. This is a step in the good direction (i.e., to recognise the problem), taking into account that lately the most common position apparently ignores the entire situation altogether (see, i.a., Kazama 2003, pp. 22-23 sub verbis [13] 'blood' and [14] 'bone').

In this paper we claim that we are dealing not with a phonological problem, but rather with one of morphology restructuration.

\section{Prolegomena}

2.1. In this paper the following internal division of the Tungusic languages is adopted: [1] Northern Tungusic (= Northwestern: Ewenki, Ewen, Solon, Negidal, Arman, Udihe), [2] Southern Tungusic (= Amurian Tungusic: Oroch, Nanay, Kilen, Kili, Ulcha, Orok), with Udihe and Oroch serving as a bridge between one branch and the other, and [3] Manchuric (Early and Late Jurchen, Written Manchu, Spoken Manchu and Sibe). The prefix "Pan-" refers to the fact that a given word is attested across dialects of Ewenki, Ewen, Solon or Udihe. "L-" before language names stands for literary, standard, e.g. LEwenki = Literary Ewenki (the standard language based in Southern dialects), etc.

As for historical stages, a two-level distinction is made: Proto-Tungusic (= PanTungusic $=$ Common Tungusic $+[3]$ Manchuric) and Common Tungusic (all languages with the exclusion of [3] Manchuric, i.e. [1] Northern Tungusic + [2] Southern Tungusic). The general assumption is made that items and features belonging to the Proto-Tungusic layer are more archaic than those belonging to the Common Tungusic layer. The term "Pan-Tungusic" refers to features present in all Tungusic languages 
regardless of their historical background (borrowed or inherited), while "Core Tungusic" refers to all historical languages of the Northern and Southern branches in opposition to Manchuric.

Abbreviations and conventions used in this paper include: 1,2,3 = person, GEN = genitive, $\mathrm{POSS}=$ possessive, $\mathrm{SG}=$ singular; $\mathrm{K}=$ unspecified velar consonant, $\mathrm{N}=$ unspecified nasal consonant, $\mathrm{V}=$ unspecified vowel; $\mathrm{V}^{\mathbf{0}}=$ vowel noun, $\mathrm{C}^{\mathbf{0}}=$ nonnasal consonant noun, $\mathrm{N}^{\mathrm{o}}=$ nasal noun, $\mathrm{NG}^{\mathrm{o}}=$ noun that ends in $/ \mathrm{y} /(\mathrm{Manchu}<\mathrm{ng}>)$; “ä” =/ə/, "." = etymological segmentation, ".i." = epenthetic $i, " / n "=$ unstable nasal; "+" = derivational nominal formant, "_" = derivational verbal formant, " $\rightarrow$ " = derivation, " $\Rightarrow "=$ analogical replacement, $\mathrm{PT}=$ Proto-Tungusic, $\mathrm{CT}=$ Common Tungusic.

2.2. Manchu preserves the use of $*+$ sa and $*+$ ta as pluraliser markers only on animated (human) referents. Furthermore, $+t a$ is used with numerals to express the idea of distribution, and when attached to verbs, it derives iteratives (see, i.a., Gorelova 2002, pp. 134-137, 243-244). Semantic developments of rather trivial nature are behind the origin of these secondary uses of the original plural formative $*+$ ta.

\section{Table 2. Distribution and meaning of Manchu formatives $+s a$ and $+/-t a$}

\begin{tabular}{|c|c|c|}
\hline $\begin{array}{l}+s a_{3} \\
\text { PLURAL }\end{array}$ & $\begin{array}{l}\text { antaha 'guest' } \\
\text { amban 'high officials' } \\
\text { gucu 'friend' } \\
\text { irgen 'people, nation' } \\
\text { giohoto 'beggar' }\end{array}$ & $\begin{array}{l}\text { antahasa } \\
\text { ambasa } \\
\text { gucuse } \\
\text { irgese } \\
\text { giohotoso }\end{array}$ \\
\hline $\begin{array}{l}+\mathrm{ta}_{2} \\
\text { PLURAL }\end{array}$ & $\begin{array}{l}\text { ama 'father' } \\
\text { asihan 'young man' } \\
\text { deo 'younger brother' } \\
\text { eigen 'husband' }\end{array}$ & $\begin{array}{l}\text { amata } \\
\text { asihata } \\
\text { deote } \\
\text { eigete }\end{array}$ \\
\hline $\begin{array}{l}+t a_{3} \\
\text { DISTRIBUTIVE }\end{array}$ & $\begin{array}{l}\text { minggan ' } 1000 \text { ' } \\
\text { juwan 'ten' } \\
\text { juwe ' } 2 \text { ' } \\
\text { tofohon ' } 15 \text { ' }\end{array}$ & $\begin{array}{l}\text { minggata '(a) thousand each' } \\
\text { juwata juwanta '(a) ten each' } \\
\text { juwete '(a) two each' } \\
\text { tofohoto '(a) fifteen each' }\end{array}$ \\
\hline $\begin{array}{l}-t a_{2} \\
\text { ITERATIVE }\end{array}$ & $\begin{array}{l}\text { ana- 'to push' } \\
\text { jafa- 'to grasp' } \\
\text { debsi- 'to fan' } \\
\text { niyece- 'to mend' }\end{array}$ & $\begin{array}{l}\text { ana-ta- 'to push repeatedly', } \\
\text { jafa-ta- 'to grasp repeatedly', } \\
\text { debsi-te- 'to fan continually' } \\
\text { niyece-te- 'to mend continually' }\end{array}$ \\
\hline
\end{tabular}

These formatives will be mentioned on various occasions, for they are involved in the creation by isomorphic accumulation of secondary, plural(iser) complexes (especially + sal, see, i.a., Grenoble and Whaley 2003, pp. 102-109) or noun class suffixes in Common Tungusic (see discussion below), therefore, they are here introduced in advance for the sake of clarity. 
2.3. By the same token, there is a series of phonetic and phonological points which are going to be brought out rather frequently. In order to avoid unnecessary repetition and cross-reference, we introduce them below:

(a) Paragogic vowel $/-\mathrm{i} /$ is automatically added to final consonants (esp. the liquids $/ 1 \mathrm{r} /$ and the nasal and velar segments $/ \mathrm{m} \mathrm{n} \mathrm{g} \mathrm{k} /$ ). It is characteristic, although not exclusive, of Southern Tungusic and Manchuric. Evidence supporting the existence of the paragogic vowel comes from both internal and external data. There are some cases where the original paragogic $i$ may became the ordinary epenthetic $i$, this is specially remarkable in Chinese loanwords, e.g. Manchu tinggin 'office, bureau, section', from 亭 ting 'pavilion, office, bureau', kenggin 'a k. of sea mammal, perhaps a k. of whale', from 鲸 jing 'whale', tanggin 'hall, chamber, office of a high official', from tang 'hall', from 堂 táng, etc. Here it is safe to conclude that the first form was *tinggi and final nasal (another class suffix) was attached later. In some contexts, paragogic vowel is lost in modern Manchu variants, e.g. Literary Manchu nimanggi 'snow', giranggi 'bone' = Sanjiazi Manchu nimiy, giray [gilyan] 'id' (see, i.a., Kim 2008, p. 29).

(b) We call "Amurian labialisation" the assimilation of final vowels (whichever their origin is, though the most common target is paragogic $i$ ), to the consonantal segments $/ \mathrm{m} \mathrm{K} /$, e.g. ${ }^{*} \mathrm{ki}>{ }^{*} \mathrm{kU}$ (where $\mathrm{U}$ stands for $/ \mathrm{o} \mathrm{u} /$ ), etc. This sound change is typical of Southern Tungusic, but it also takes its effect on some varieties of Northern Tungusic found over the Lower Amur on an areal basis.

(c) Sequences /ng/ and /nk/ automatically become [ng] and [nk] in Tungusic (in Manchu transliteration $<\mathrm{ngg}>$ and $<\mathrm{ngk}>$, respectively). It is important to note that although the stop segment in [ $\mathrm{gk}]$ may be the subject of assimilation yielding [ $\mathrm{gg}]$, sequences $\eta K$ (where $\mathrm{K}$ stands for $/ \mathrm{k} /$ or $/ \mathrm{g} /$ ) never simplify to $\eta$. Put differently, no internal evidence supports the sound change $\eta K>\eta$ in the inherited vocabulary. Manchu spelling $<$ ngg $>$ is not a good historical device, insofar as in theory it does not distinguish between /y/ and /ng/ (note, however, that $<$ ngg $>$ and $<$ ngk $>$ distinguish the nature of the stop segment).

\section{Towards a Possible Solution}

There are three derivational suffixes of the shape +nggi in Manchu: (1) missive $-n g g i$ which is attached to verb bases, e.g. ala- 'to tell, report' $\rightarrow$ ala-nggi- 'to send someone to report', the etymology of which is transparent: unggi- 'to send' in the verb construction X-me unggi- 'to send s.o. to X', (2) adjectival $+n g g i$, as in ete- $n$ 'force, resistance' $\rightarrow$ ete-nggi 'strong, powerful', and (3) the formative in words like senggi or giranggi. Manchu grammars briefly describe the first two formatives (see, i.a., Gorelova 2002, pp. 115, 250), but make no mention of (3). The division can be established not on the apparent Tungusic etymology of Manchu $+n g g i$, but rather on semantic class.

The discussion hereafter concerns (3) and there will be a cursory inspection regarding (2). 


\subsection{Common Tungusic $+k s a$ and $+k t a$ vs. Manchu + nggi and $+h a_{3}$}

Benzing's *-g-sA specifies masses of uncountable materials, like liquids and other substances, e.g.

[1] Manchu silenggi 'dew' $<*$ silä+ksä ${ }^{3}>$ LEwenki siläksä

[2] Manchu imenggi 'vegetable oil' < *ximö(ö)+ksä 'fat' > LEwenki imuuksä ${ }^{4}$ (note that Manchu $-e$ - is the result of contamination with [4])

[3] Manchu giranggi 'bone' < *gïram+sa 'skeleton; bone' > LEwenki giramna 'skeleton', but LNanai germaksa 'bone'

[4] Manchu nimenggi 'oil, fat' < PT *nimä/n+sä '(intestine) fat' > LEwenki nimnä 'stomach (of animals)', LEwen nimnä 'intestine fat'

[5] Manchu nimanggi 'snow' < PT *xïma/n+sä 'snow' > LEwenki imana, LEwen їmёnrë (Manchu $n$-results from assimilation of the original sequence $* \mathrm{hVmV}$ ).

For [4] and [5], there is general consensus regarding the reconstruction of $* / n$.sa and the ulterior simplification of the three-consonant cluster /...Cns/via perhaps haplology, thus LEwenki nimnä 'stomach (of animals)' <**nim(ä)N-nä <*nimä/n-sä 'intestine fat' (cf. Orok numisä, also with simplification) and imana 'snow' $<* * i \mathrm{~m}(\mathrm{a}) \mathrm{N}$ nä < *xïma-n.sä 'id.' (Orok sïmata sïmana reflects either an anomalous result of */n.sä or secondary analogical leveling with $*+$ ta, rather than the existence of a competing formation *xïma-n.tä at the parent language level), whereas LEwen imënrë shows the regular development $*_{\mathrm{ns}}>/ \mathrm{nr} /$.

The semantic and morphological correspondence is constant and consistent even when the nominal bases are not cognates, e.g. Manchu obonggi 'foam, bubble' vs. LEwenki cowiiksa 'foam; saliva', or Manchu fongsonggi and yalmanggi (or yenmanggi), both meaning 'soot, dirt' vs. LEwenki uwuksa or LNanay xufäksä 'id.' .

In contrast, Core Tungusic nouns with class suffix $+k t a<*+$ g-ta (Benzing 1956, pp. 71-72, §80), which singles out members of groups of countable objects, systematically correspond to Manchu nouns with $+h a_{3}$, which is not taken into account in Manchu grammars (as for the elusiveness of this formative, Gorelova's

${ }^{3}$ The underived noun base *silä 'dew, rime; rain(drops), drizzle' shows vowel assimilation in Core Tungusic languages, e.g. LEwenki sili, LEwen hiili, etc. (SS 2.85-86, EEWTD [9685]), cf. Udihe silihä $<*$ silä+ksä. Curiously enough, *silä has no correlate in Manchu(ric) most likely because Mongolian silün 'meat soup, broth' < Mongolic *silön $\rightarrow$ Tungusic *silä(.n) (> Manchu sile 'soup') merged with what would have become the regular outcome of *silä, i.e., **sile (Rozycki 1994, p. 181, SS 2.85 s.v. silä 'soup' and EEWTD [9681]).

${ }^{4}$ Medial long vowels in Northern Tungusic may have resulted after compensatory lengthening when three-consonant clusters simplified, e.g. East Ewenki uliikta, Solon uliittä, LUdihe uligkiä, Ulcha \& LNanai uñiktä $<*$ unin-ktä $<*$ uli $/ \mathrm{n}+\mathrm{ktä}$, cf. Manchu uli 'fruit of the flowering cherry (Prunus sinensis or Prunus japonica)', from Proto-Tungusic *uli/n $\rightarrow$ Common Tungusic *uli.n+ktä 'wild apple' (SS 2.261a), or LEwenki sayiiksa 'hoar-frost, rime', cf. Udihe sayuhce < *sayo.n+ksa id., from Common Tungusic *sayo/n 'coolness' > Orok saynü or Kili sayniksa (both with metathesis; SS 2.62-63). As for Manchu $u l i<* u l i / n$, the loss of *../n may be due to contamination with Chinese 郁李 yùlì 'plum' (cf. SS 2.260b) or, perhaps, to avoiding homonymy with ulin 'goods, property, wealth'. 
(2002, pp. 114-115, 595, 596) description "morpheme which is a final component of nominal stems" is eloquent enough):

[6] usiha 'star' <*xoos(.)ï+kta ${ }^{5}>$ LEwenki oosikta

[7] uriha 'inner bark of trees' $<*$ xur(.)i+kta $>$ LEwen ürtz̈, Ulcha xurakta

[8] funiyehe /fuñexe/ 'hair' < *puñä+ktä > LEwenki hänäktä 'fur of young deer'

[9] sirhe 'sinew, thread' < *sirä+ktä > LEwenki siräktä.

Benzing was perplexed about the historical results in Manchu. Since Benzing and many others assumed that Manchu evolved from a language closer to Core Tungusic, the assumption was made that $+n g g i$ must necessarily continue $*+\mathrm{ksa}$, whereas $*+\mathrm{kta}$ continued as $+h a .^{6}$ The latter evolution seems regular, because *-k- > Manchu $-h$-, therefore one can suggest that the consonant cluster $/ \mathrm{kt} /$ was simplified to $/ \mathrm{k} /$, which regularly yields Manchu $h$. We will show below why this reasoning is faulty on various accounts.

\subsection{Internal Reconstruction and the Components of $*+k t a$ and $*+k s a$}

We agree with Benzing that $*+\mathrm{kta}$ and $*+\mathrm{ksa}$ are suffixal complexes and they can be segmented into two parts: ${ }^{*} \mathrm{k}$ and $*$ ta or $*$ sa. The second component has transparent counterparts in Manchu (see above) which match both phonetically and semantically. The nature and origin of the first component $* \mathrm{k}$, however, is less obvious.

Benzing (1956, p. 69) proposed that this formative might be the same $*+g$ which shows plural or collective semantics in Northern Tungusic, e.g. Northern Tungusic *cuuka 'straw' $\rightarrow$ *cuuka+g 'meadow' > LEwenki cuuka $\rightarrow$ cuuka-g, Lower Amgun Negidal cooxa $\rightarrow$ cooxa-g, LEwen cöökä $\rightarrow$ cöökä-g 'id.' (SS 2.411a, EEWTD [2219]), or perhaps Common Tungusic *sya+kta 'willow' $\rightarrow$ Northern Tungusic *syakta.g 'osier-bed' (EEWDT 708[9508], note that Doerfer's reconstruction *syaa- with long vowel /aa/ cannot be confirmed, as diphthongoids yield long vowels so that /aa/ could be in theory from either*/sya-/ or */syaa-/; SS 2.70a), cf. LEwenki $\&$ Negidal seektag, LEwen hëëta $+k a . g(+k a$ is the diminutive $+k a n){ }^{7}$

\footnotetext{
${ }^{5}$ For the (potential) presence or absence of epenthetic $i$ (or $i$ depending on vowel harmony requirements), see Alonso de la Fuente (2013a).

${ }^{6}$ It should be clear that Udihe + ha, cf. silihä $<$ [1], geämaha $<$ [3], imoho $<$ [4], and imaha $<[5]$ is the natural evolution of $+k s a$, and this must not be taken as parallel to the evolution leading to Manchu $+h a_{3}$.

${ }^{7}$ See more examples in Boldyrev (1987, pp. 181-185). Miller (1994, p. 292) argues that the distribution of Benzing's "Kollektivsuffix (?) *+g" is very limited and consequently it is necessary to seriously consider whether we are dealing with an exclusively Northern or Southern element rather than with a Proto-Tungusic suffix. It is our intention to present an alternative scenario here whereby parent language suffix $*+\mathrm{g}$ disappeared altogether in some languages after the fusion with ${ }^{*}+$ sa and $*_{+}$ta took place. We make the assumption that the retention of $*+g$ in Northern Tungusic can be seen as an archaic feature of this branch, instead of an innovation.
} 
Benzing's reasoning regarding the identification of the first component in noun class suffixes ${ }^{*}+\mathrm{kta}$ and ${ }^{*}+\mathrm{ksa}$ as well as the reason why it does not surface in Manchu seem correct. However, we will argue that ${ }^{*}+\mathrm{g}$ is preserved in Manchu, but only after particular developments had taken place.

\subsection{Not Phonology, but Morphology}

The mystery surrounding the origin of Manchu +nggi can be solved, as is often the case, if we change perspectives. Instead of assuming that the problem concerns phonology, we will set up a scenario where the most important role is played by morphology.

Already in the parent language, nouns belonged to three classes, the classification of which depends on what segment occupies the last position in the word or base: vowel nouns $\left(\mathrm{V}^{\circ}\right)$, non-nasal consonant nouns $\left(\mathrm{C}^{\circ}\right)$ and nasal consonant nouns $\left(\mathrm{N}^{\circ}\right)$, of which the second was the least numerous. This system has been inherited by the majority of Core Tungusic languages. In the history of Manchuric, however, non-nasal consonant nouns were lost (via the introduction of paragogic vowel, or either the replacement with...$/ n$, or complete loss of the given consonant). This well-known internal development of Manchuric can be observed in more recent times, starting already in Jurchen times, in regards to the phonological treatment of loanwords.

The starting point for our scenario requires us to make the following assumption: noun class suffix $*+\mathrm{g}$ already existed in the parent language, that is, this noun class suffix was not restricted to Northern Tungusic, but belonged to the derivational morphology of Proto-Tungusic. This formative developed paragogic $i$ as expected from non-nasal final consonants in Manchuric, hence the variant *+g.i. As we have seen, this requirement does not apply to Northern Tungusic, therefore we can assume that the presence of paragogic $i$ is a Manchuric innovation. It is important to note that the sound change Proto-Tungusic $*_{\text {-g- }}>$ Manchu $\varnothing$ (Benzing 1956, p. 30, $\$ 41[\mathrm{c}]$ ) is blocked when the second vowel is epenthetic or paragogic.

Noun class suffix $*+$ g.i could occur with both vowel and nasal vowels, e.g. ${ }^{* *}$ se- $\rightarrow{ }^{* *}$ segi 'blood' and giran 'corpse (<*skeleton)' $\rightarrow$ giranggi 'bone'. One would expect to find formations like **segi at some point in the history of Manchuric. As a matter of fact, such formations exist: Manchu sogi 'vegetables' or tugi 'clouds'. Let's focus on the latter for the sake of illustration: PT *tö+g.ï '(dark?) clouds, cloudy' is the immediate predecessor of LEwenki tugä, Upper Amgun Negidal tugä $\sim t u w \ddot{a}$, Oroch tuä, LUdihe tuä, LNanay tuä or Ulcha tuä 'winter' (SS 2.204-205) with regular $*_{-}$- $->\varnothing$ in Southern Tungusic, Oroch and Udihe, and the unexpected $*_{-i}>*_{-a ̈}$ due to contamination with the name of other periods of the year (cf. LEwenki jugä 'summer', ñängñä 'spring', but bolo 'autumn'). Once the semantic development '(dark) clouds > winter' had taken place, the collective suffix ${ }^{*}+$ ksa was added in Core Tungusic languages to generate a new term for 'cloudy' (that is, Common Tungusic *tög.ï+ksä $\sim$ *tögä+ksä > *töö+ksä even in Northern Tungusic, see SS 2.208209, EEWTD [11115], Doerfer 1984, p. 80 [33] etc.). Note that Manchu tuweri 'win- 
ter' < pre-Manchuric *tugi+ri shows regular *-g- $>\varnothing$ because here $*_{\mathrm{i}}$ in $*_{\mathrm{g} . \mathrm{i}}$ is interpreted as being the regular $*_{\mathrm{i}}$, and not the paragogic vowel that blocked the loss of *g between vowels.

We will show below why these words are very valuable archaisms.

A major change takes place when the morpheme boundary in nasal nouns is reanalysed $^{8}$ : the nasal element in nasal nouns is transferred to the noun class suffix under the pressure of the overwhelming majority of vowel nouns. The loss of - $g$ - in intervocalic position may also have contributed to the general reanalysis of these formations. Be that as it may, the internal composition of words like giranggi is reinterpreted as being made of $* *$ gira and $+n g g i$, instead of the correct, etymological analysis $* *$ giraN plus $*+$ gi. This leads to the generalisation of $+n g g i$ to vowel nouns, hence the replacement of *segi with senggi.

\section{Table 3. Analogical reanalysis of nasal nouns with noun class suffix $*+g . i$}

\begin{tabular}{|c|c|c|c|c|}
\hline & & & Stage I & Stage II \\
\hline $\begin{array}{l}\text { *gïram 'skeleton' } \\
\text { (> giran 'corpse') }\end{array}$ & $\rightarrow$ *gïraN+g.i & $>$ & & giranggi \\
\hline$*_{\text {silä }}{ }^{9}$ & $\rightarrow *_{\text {silä}+\mathrm{g.i}}$ & $>$ & $* *$ silei $^{10} \Rightarrow$ & silenggi \\
\hline
\end{tabular}

It is only natural that Jurchen, the historical stage prior to Manchu, would preserve more of these formations. But before addressing Jurchen data, we need to clear out the way by explaining the origin of +nggi in words like Manchu etenggi. Curiously enough, Jurchen proves crucial in doing so.

${ }^{8}$ Reanalysis or reinterpretation of morphological structure (including subtypes such as metanalysis, backformation, etc.) is the simplest of morphological changes. Therefore, it is well covered in the specialist literature on historical linguistics (see, i.a., Hock 1991 [1986], pp. 176179; Crowley 1994 [1992], pp. 145-147; Campbell 2000 [1998], pp. 102-103; Hock-Joseph 2009 [1996], pp. 166-167; Miller 2010, pp. 133-142; Millar 2015 [1996], pp. 96-99).

${ }^{9}$ It could be argued that such forms as Ulcha \& LNanay silämsä or Oroch silänsä support the reconstruction of the nasal noun *silä-n, from which it is much easier to arrive at Manchu silenggi (nouns drop the n-ending in the formation of the plural, but sometimes it is preserved during nominal derivation). However, the $m$-element cannot be derived from $/ \mathrm{n} /$ under any rational circumstance. Moreover, there are good reasons to think that the $m$-element might actually be another formative, already fossilised in the parental language, carrying the meaning of collectiveness or the like, e.g. LEwenki urumya 'earwax', Ulcha \& LNanay xoromsa, Orok xoropsa < Proto-Tungusic *xöröm+ksa or LEwenki Ulcha pü̈̈msa, Orok püpsa < Common Tungusic *puwu.m+ksa 'sawdust' $\leftarrow$ Proto-Tungusic *puwu- 'to saw' (VS §79[d]). The loss of medial $-k$ - in the sequence *-.m+ksa is regular, as three-consonant clusters are disliked in Tungusic. There is no trace of this element in Manchuric.

${ }^{10}$ Jurchen †šilei 'dew' (Kane 1989, p. 137[11]) could be the irregular continuation of *silägi, with *-g- $>\varnothing$, although in theory this sound change is cancelled when *g is followed by the epenthetic or paragogic vowel. It must be noted that this case is not isolated, cf. Manchu jortanggi =jortai 'deliberately, willfully'. 


\subsection{Manchu etenggi and Related Words}

As we have mentioned above, there is another suffix of the form $+n g g i$ in Manchu. It is also unproductive and seems to change regular nouns into possessive adjectives (there are some examples that apparently involve verbs, e.g. naranggi 'finally, after all' $\leftarrow$ nara- 'to long for, feel attached'):

\section{Table 4. Manchu words with possessive adjectives in +nggi}

\begin{tabular}{ll}
\hline atanggi 'when?' & $?$ \\
bardanggi 'braggart' & $\leftarrow$ Mong. barda- (Rozycki 1994, p. 25) \\
cananggi 'previously' & $?$ \\
dedenggi 'frivolous, loose' & $\leftarrow$ dede dada 'restless' \\
elenggi 'slovenly, lazy' & $\leftarrow$ elen 'sufficiency, goal' \\
enenggi 'today' & $\leftarrow$ ene 'this' (?) \\
etenggi 'hardy, strong' & $\leftarrow$ eten 'force, resistance' \\
fiyalanggi 'a loose talker' & $\leftarrow$ fiyalar seme 'loosely, wildly (of speech)' \\
gojinggi gojingga 'fast-talking' & $\leftarrow$ gojong seme 'fast and unclear (of speech)' \\
inenggi 'day' & cf. Proto-Tungusic *inä+n(.i) $\leftarrow$ *inä- 'to dawn' \\
kalcunggi 'high-spirited' & $\leftarrow$ kalcun 'spirit, energy' \\
lebenggi 'swampy, marshy, damp' & cf. LEwenki läwää id. (SS 1.514) \\
susenggi 'sloppy, dirty' & $\leftarrow$ suse 'crude, trash' \\
tunggi 'bent over, curved' & $\leftarrow$ tung moo 'Vernicia fordii (or tung tree)' \\
unenggi 'truly, really, honestly' & $?$ \\
yalanggi 'true, genuine' & $\leftarrow$ yala 'truly, indeed' \\
\hline
\end{tabular}

It is has been traditionally assumed that the suffix $+n g g i$ in these Manchu words is connected to Mongolic $+k i$, that is, ${ }^{*} \ldots \mathrm{n}+\mathrm{ki}>+n g g i$ (see, i.a., Ramstedt 1952, pp. 234-235 or Poppe 1987, p. 187). This assumption grew out of the fact that both denominal and deverbal adverbs and adjectives in Manchu have $+k i$ very much as in Mongolic where adverbs and adjectives are the main target of $+k i$. But we can safely conclude that it has nothing to do with Mongolic $+k i$ (or its variant $+h i$ ). As is well known, consonant clusters of the type *-NK- do not yield Manchu $-N G$ - under any circumstance.

${ }^{11}$ One of the reviewers suggests instead the adjectival form bardang 'braggart'. In that case, it cannot be said that Manchu bardanggi contains the suffix $+n g g i$, because the most economical solution is to make the assumption that Manchu had simply added the paragogic vowel $-i$ as in the Chinese examples explained above (with bardanggi being the regular continuation of *bardang-i). 
Table 5. Manchu adverbs and adjectives with $+k i$ and $+h i$

\begin{tabular}{|c|c|}
\hline \multicolumn{2}{|r|}{$+k i$} \\
\hline ada- 'to accompany' & adaki 'neighbour' \\
\hline amba 'big' & ambaki 'haughty, proud, pompous' \\
\hline dursun 'likeness, shape, form' & dursuki 'similar' \\
\hline goro 'far' & goroki 'distant, far' \\
\hline hanci 'near' & $\rightarrow$ hanciki 'near' \\
\hline jabšan 'good luck' & jabšaki 'good fortune' \\
\hline juse 'children' & juseki 'childish' \\
\hline sakda 'old' & sakdaki 'looking old' \\
\hline \multicolumn{2}{|r|}{$+h i$} \\
\hline$a d u$ 'garment' & aduhi 'leather trouser' \\
\hline aci- 'to load' & acihi 'stake, share' \\
\hline dasi- 'to cover, shut' & dasihi 'dust, dirty' \\
\hline dobi 'fox' & dobihi'a fox pelt' \\
\hline sinagan 'mourning' & sinahi 'mourning garment' \\
\hline wasi- 'to descend, fall, sink' & wasihi 'clumsy, awkward' \\
\hline
\end{tabular}

Furthermore, as a cursory inspection of the sections devoted to birds, various animal types, and insect names in the pentaglot dictionary 五體清文鑑 Wǔtǔ qìngwénjiàn reveals (Corff 2013, pp. 2.899-992), the suffix $+k i \sim+h i$ occurs in numerous zoonyms due to the fact that, by virtue of popular etymology, they are linked to particular objects, shapes, activities, etc. (cf. Bolderyv 1987, pp. 46-53) ${ }^{12}$ Note that both $+k i \sim$ thi may appear with the same base, e.g. lekerki lekerhi 'sea otter' or šosiki $\sim$ šosihi 'chipmunk'. ${ }^{13}$ There are no zoonyms showing + nggi.

The case can be made on both semantic and phonetic grounds that words in Table 4 contain a suffix $+n g g i$ that is cognate of the Common Tungusic alienable suffix $*+\operatorname{yi}(+)$ which is usually linked to the Manchu genitive on the account that there is no genitive in Core Tungusic languages and Manchuric lacks the category of alienability (see Tsumagari 1997, pp. 178-183). ${ }^{14}$

${ }^{12}$ As a matter of fact, even when the etymology is more or less clear, this requires a great deal of elaboration. For example, Manchu lekerki lekerhi 'sea otter (Latax lutris)' is based on a metaphoric development: the sharp teeth of sea otters remind of whetstone, cf. Manchu leke 'whetstone, grinding stone' and leke- 'to sharpen, to grind on a whetstone' (see i.a. EEWTD [6793]). Later analogies gave birth to other derivates, such as lekeri 'spiral shell used as a horn' and lekerhin 'seal'.

${ }^{13}$ Näher (1988) has convincingly demonstrated that the sound change Proto-Tungusic *-k$>$ Manchu $-h$ - takes place in inherited lexicon or very old loans, whereas ${ }^{(*)}-\mathrm{k}->$ Manchu $-k$ - is restricted to the most recent borrowings.

${ }^{14}$ A detailed account of the historical and typological implications of this comparison goes well beyond the scope of this paper (see, i.a., Menges 1978, pp. 381-382, where the same semantic bridge is mentioned). As for the original function of Proto-Tungusic $*+n(. i)$, we cannot be more 
Table 6. Manchu zoonyms with $+k i$ and $+h i$

\begin{tabular}{ll}
\hline$+k i$ & $+h i$ \\
\hline horki 'the Siberian capercaillie' & fijirhi 'wildcat' \\
kûwatiki 'a one-year-old bear' & huwethi 'seal' \\
niyociki 'a kind of small bird' & malahi 'a striped yellow wild cat' \\
sotki 'sea carp' & silihi $\sim$ solohi 'weasel' \\
turaki 'jackdaw' & tarbahi $\sim$ tarbihi 'marmot' \\
\hline
\end{tabular}

In sum, we are dealing with two different suffixes, noun class suffix *+g(i) and possessive adjective $*+$ ni, which are homophonous in Manchu. We will explain below how they come to be homophonous in Manchu. But before doing so, we have to account for the fact that they are not homophonous in Jurchen.

\subsection{Jurchen Data}

Jurchen confirms the existence of the stage when noun class suffix *+gi was attached directly to vowel nouns. Jurchen data show that nasal nouns lost the nasal component to become vowel nouns.

Table 7. Proto-Tungusic * $+g(. i)$ in Jurchen and Manchu

\begin{tabular}{|c|c|c|c|}
\hline $\begin{array}{c}\text { Jurchen } \\
\text { words with 尽 }\end{array}$ & Manchu & Comments & $\begin{array}{l}\text { Kiyose } \\
\text { (1977) }\end{array}$ \\
\hline †tugi 'cloud' & tugi & See discussion above & 006 \\
\hline †imagi ‘snow' & nimanggi & See above [6] & 017 \\
\hline$†$ †ulegi 'ashes' & fulenggi & See above [2] & 065 \\
\hline $\begin{array}{l}\dagger \text { 'sogi } \\
\text { 'vegetable(s)' }\end{array}$ & $\begin{array}{l}\text { sogi } \\
\text { 'vegetables' }\end{array}$ & $\begin{array}{l}<\mathrm{PT} * \text { solgi }+\mathrm{g} . \mathrm{i}^{15} \rightarrow \mathrm{CT} * \text { solgi }+\mathrm{ksa}> \\
\text { Oroch soggixa, Udihe sogühö, cf. Nanay } \\
\text { solge, Ulcha solji }<* \text { soldi }<* \text { solgi }(\mathrm{SS} \\
2.103 \mathrm{a} \text { ) }\end{array}$ & $\begin{array}{l}134, \\
524\end{array}$ \\
\hline †segi ‘blood' & senggi & See discussion below & 512 \\
\hline †imegi ‘oil' & nimenggi & See above [3] & 526 \\
\hline
\end{tabular}

precise at present. However, we believe that the comparison is not far-fetched and can be valid as a working hypothesis until a more detailed study is conducted.

${ }_{15}$ Although somewhat arbitrarily, we interpret that haplology targeted /gi/ in the base, and not in the ending, as the ending conveys morphological information crucial for the proper understanding of the word. 
Interestingly enough, all Jurchen words with *+gi shown in Table 7 have been transliterated in Chinese with 吉, whose Jurchen equivalent Kiyose (1977) and Kane (1989) read †gi. They propose the same reading for another set of words with Jurchen 质. As shown in Table 8, words with Jurchen质 seem to contain the possessive adjective suffix $+n g g i$. We believe that noun class suffix $*+$ g.i $>$ Jurchen 天, whereas possessive adjective $*+$ y.i $>$ Jurchen 㡸 (see Alonso de la Fuente 2013b, pp. 105-106), as in the following examples in Table 8 (note that $\mathrm{A}=$ Kane 1989, $\mathrm{H}=$ Kiyose 1977). It turns out, therefore, that the merger of $*+$ gi and $*+$ ni did not occur in Jurchen times (mainly due to the fact that, as we have seen above, the analogical reanalysis leading to the transfer of the nasal element of nasal nouns to the noun class suffix did not take place in Jurchen):

Table 8. Jurchen 实 vs. 派

\begin{tabular}{|c|c|}
\hline 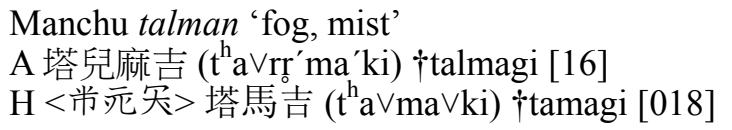 & $\begin{array}{l}\text { Manchu šumin 'deep' } \\
\mathrm{H}<\text { 全兵质> 舒迷吉 (symi'ki) } \\
\text { †šmigi [695] }\end{array}$ \\
\hline 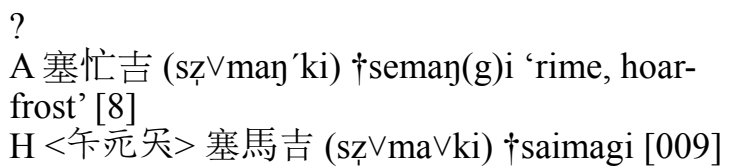 & $\begin{array}{l}\text { Manchu ice 'new' } \\
\mathrm{H}<\text { 米质>一車吉 }\left(\text { ji ts }{ }^{\mathrm{h}} \varepsilon \mathrm{ki}\right) \\
\text { †icegi [666] }\end{array}$ \\
\hline
\end{tabular}

Jīn (1984: sub verbis $101 \dagger$ †ji, 226 †gi) reads †tamangi, †saimangi, †šumigi, and $\dagger$ icegi, respectively. Based on the discussion above, we propose to reverse Jinn's interpretations and read 灾 $=/ \mathrm{gi} /{ }^{16}$ and 㡸 $=/ \mathrm{yi} /$, so that Jurchen data can be directly confronted with etymological and comparative materials. Thus, Jurchen adjectives like †šumin(g)i (related to Manchu šumin < Proto-Tungusic *syum $\pm \rightarrow$ Common Tungusic *syum-kta 'deep'> LEwenki suyta id., see Alonso de la Fuente 2013b) and †icen(g)I (< Proto-Tungusic *xirkä > Common Tungusic *xirkä+kyän [cf. EEWTD 5401 *hirkä+küün] 'new, recent' > Sakhalin Ewenki irkäkiin, Negidal ixixiin, Kili itkäkin', Kilen siku(n-), Ulcha sicäu(n-), Orok sitäw sitäu, both with Amurian labialisation $*_{-k i}>*_{-k u}>-\varnothing u$, see SS 1.328a) contain the same possessive adjective suffix $+n g g i$ that shows up in words like Manchu etenggi and directly continue Proto-Tungusic ${ }^{*}+$ yi $(+)$. On the other hand, we have Jurchen †talmagi (< Proto-Tungusic *talma + g. $i$ Common Tungusic *tamna+k-sa 'fog' > LEwenki tamnaksa, see Alonso de la Fuente 2012) and †saimagi (= LEwenki siniksä) which contain the direct outcome of ProtoTungusic $*+g$ before it was analogically replaced in Manchu with $+n g g i$.

This interpretation makes more believable the following set of comparisons involving Jurchen words with 质 and Manchu words with $+n g g a_{3}$, a suffixal complex made of the alienable suffix *+ni and, perhaps, an unidentified element carrying har-

${ }^{16}$ See the use of 穴 as / $\mathrm{yi} /$, transcribed with Chinese 更 $g e \bar{e} g<$ Yuan $\dagger$ kin, see Pulleyblank (1991, p. 107) in †nogila- 'to attach' [H 41, 449] = Manchu nonggi- 'to add, increase' and †segige 'relatives' [H 328, 408], Jīn † 
monic vocalism. If we replace Kiyose's reading $\dagger$ gi with $\dagger y(g) i$, the comparison with Manchu $+n g g a_{3}$ becomes more realistic and provides some context for further discussion regarding the origin of the Manchu suffix and its potential cognate in Jurchen.

Table 9. Jurchen 派 vs. Manchu + ngga $_{3}$

\begin{tabular}{|c|c|c|c|c|}
\hline \multicolumn{2}{|c|}{$\begin{array}{c}\text { Kiyose's reading } \\
\text { 质 }=\text { †gi }\end{array}$} & $\begin{array}{c}\text { Our reading } \\
\text { 质 }=\dagger \eta(\mathrm{g}) \mathrm{i}\end{array}$ & Manchu & Comments \\
\hline $\begin{array}{l}\text { ttihaigi } \\
\text { 'according; } \\
\text { following' }\end{array}$ & $\begin{array}{l}{[470],} \\
\text { etc. }\end{array}$ & †tihain(g)i & $\begin{array}{l}\text { cihangga 'will- } \\
\text { ing, eager' } \leftarrow \\
\text { cihai 'wish, de- } \\
\text { sire' }\end{array}$ & - \\
\hline $\begin{array}{l}\dagger \text { 'mangi urgujere } \\
\text { 'to be joyful' }\end{array}$ & [749] & $\dagger \operatorname{man}(\mathrm{g}) \mathrm{i}$ & $\begin{array}{l}\text { mangga } \\
\text { 'strong, hard' }\end{array}$ & $\begin{array}{l}\text { Cf. Manchu urgunje- } \\
\text { 'to rejoice, be glad' } \\
\text { (mangga takes the } \\
\text { meaning of 'often, usu- } \\
\text { ally' when it co-occurs } \\
\text { with imperfective par- } \\
\text { ticiples, see i.a. Gore- } \\
\text { lova } 2002 \text {, p. } 154 \text { ) }\end{array}$ \\
\hline $\begin{array}{l}\dagger \text { 'cucuwahai gelegi } \\
\text { 'according to the } \\
\text { rule' }\end{array}$ & [824] & †geley $(\mathrm{g}) \mathrm{i}$ & - & $\begin{array}{l}\text { See †geley }(\mathrm{g}) \mathrm{i}= \\
\text { koolingga 'prescribed, } \\
\text { ordered' } \leftarrow \text { kooli 'rule, } \\
\text { norm, statue' (note that } \\
\text { the order is inverted to } \\
\text { parallel the Chinese } \\
\text { equivalent, cf. Kiyose } \\
1977, \text { p. } 143 \text {, fn. } 339 \text { ) }\end{array}$ \\
\hline †fuligi 'destiny' & [26] & $\dagger$ fuling(g)i & $\begin{array}{l}\text { fulingga 'lucky, } \\
\text { having good } \\
\text { fortune' }\end{array}$ & - \\
\hline †eregi jai ‘hereby’ & {$[731]$} & $\dagger \operatorname{eren}(\mathrm{g}) \mathrm{i}$ & - & $\begin{array}{l}\text { See } \dagger \text { eren }(\mathrm{g}) \mathrm{i}=\text { ereni } \\
\text { 'by this, through this, } \\
\text { from this' (cf. Manchu } \\
\text { jai 'next, following') }\end{array}$ \\
\hline †jaagi ‘easy’ & [703] & †jaay $(\mathrm{g}) \mathrm{i}$ & - & $\begin{array}{l}\text { Cf. Manchu ja 'cheap, } \\
\text { easy' }\end{array}$ \\
\hline $\begin{array}{l}\text { †emu hergegi 'one } \\
\text { rank' }\end{array}$ & {$[853]$} & †hergen $(\mathrm{g}) \mathrm{i}$ & - & $\begin{array}{l}\text { Cf. Manchu hergen } \\
\text { 'title, rank' }\end{array}$ \\
\hline
\end{tabular}


These words may be a remnant of the stage when +nggi was still not being replaced by $+n g g a_{3}$ as one of the most productive adjectival suffixes, in the very same way that Manchu tugi or sogi are true archaisms (in Manchu their use is restricted to collocations ${ }^{17}$ ) that bear testimony to a stage of the language prior to the analogical extension $+g i \Rightarrow+n g g i$.

Categorical statements to the effect that there are no Manchu cognates for Jurchen words with †+gi like †rumigi 'deep' should be subject to revision (see, i.a., Pevnov 2005, p. 138).

It is imperative to underline the very important fact that the apparent distinction carried by 实 and 质 is purely etymological. To the best of our knowledge, there is no internal evidence from the Chinese side that would support these readings. It is only the comparison with other Tungusic languages and our (for the time being, admittedly, rather rudimentary) interpretation of the data that enables us to propose two different formatives.

\subsection{Consequences for the Reconstruction of Noun Class Suffixes in Proto- Tungusic}

There is nothing wrong with the previous scenario showing that Manchuric has preserved a very ancient layer of derivational morphology of the parent language. As a matter of fact, it is easier to stick to this line of reasoning and make the assumption that formations like *silä $+g$ ( $>$ Manchuric *silägi, etc.) were replaced in Core Tungusic with *siläktä. For unknown reasons, some nouns were required to additionally attach $*+$ ta or $*+$ sa, most likely due to semantic considerations. In such cases, loss of semantic contents is the trigger to create new, suffixal complex that would prevent the total opaqueness of a given word.

It follows naturally that if our reasoning is correct, we do not have to accept the idea that $*+\mathrm{ksa}$ and $*+\mathrm{kta}$ are Proto-Tungusic elements anymore. Manchu derives from a language where these isomorphic formations did not exist. They developed independently when Manchuric branched off.

This atomistic analysis of noun class suffixes makes stronger the assumption that perhaps another formative of the form $*+\mathrm{kV}$ existed along $*+\mathrm{g}$. In sharp contrast to $*+\mathrm{g}$, this mysterious formative $*+\mathrm{kV}$ shows vowel harmony in Manchuric. This has been taken, together with the viability of the $* \mathrm{kt}>h$ sound change, as prima facie evidence supporting the evolution *+kta $>$ Manchu $+h a$. We argue that there is an alternative, much more natural and economical explanation, for the origin of Manchu $+h a$.

The fact that Manchu tha has harmonic variants speaks in favour of the total integration of the formative within the morphological system of the language. This confirms that we are dealing with a rather old formative.

${ }^{17}$ To this group also belong Manchu niyaki /ñaki/ 'pus, nasal and bodily discharge' $<*$ ñaa \pm 'to rot; pus' $\rightarrow$ *ñaaksa > Ewenki ñaaksa 'id' and Manchu šugi $\sim$ šuhi 'fluid, clear juice, clear discharge, vital fluid of the body, extract' <*syuksä > Ewenki cuuksä 'id'. 
Table 10. Harmonic variants of Manchu $+h a_{3}$ and LEwenki $+k t a_{3}$

\begin{tabular}{|c|c|c|c|}
\hline Manchu & LEwenki & Common Tungusic & References \\
\hline bosho 'kidney, waist' & bosokto & *bosa + kta & $\begin{array}{l}\text { SS } 1.97 \\
\text { EEWTD [1343] }\end{array}$ \\
\hline $\begin{array}{l}\text { muciha 'bamboo splints } \\
\text { or rushes for making } \\
\text { baskets and mats' }\end{array}$ & $\begin{array}{l}\text { mucuktä 'branches } \\
\text { of conifer' }\end{array}$ & $\begin{array}{l}{ }^{*} \text { muci+kta } \\
{ }^{*} \text { möci+ktä }\end{array}$ & $\begin{array}{l}\text { SS 1.562 } \\
\text { EEWTD [7299] }\end{array}$ \\
\hline orho 'grass, hay, plant' & oro(o)kto & $\begin{array}{l}\text { *oraa }+ \text { kta } \\
\text { *oroo+kta }\end{array}$ & $\begin{array}{l}\text { SS } 2.24 \\
\text { EEWTD [8868] }\end{array}$ \\
\hline $\begin{array}{l}\text { uriha 'the tender (in- } \\
\text { ner) bark of trees or } \\
\text { the thin skin of nuts' }\end{array}$ & (LNanai horakta) & *xura + kta & SS 2.282 \\
\hline usiha '1. star' & oosiikta & 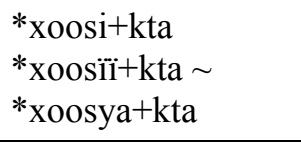 & $\begin{array}{l}\text { SS } 2.27 \\
\text { EEWTD [8983] }\end{array}$ \\
\hline usiha '2. acorn' & usikta 'oak tree' & $\begin{array}{l}\text { *xusi+kta } \\
\text { *xusi }+ \text { kta } \\
\end{array}$ & $\begin{array}{l}\text { SS } 2.291 \\
\text { EEWTD [8993] }\end{array}$ \\
\hline $\begin{array}{l}\text { wasiha 'claw, finger- } \\
\text { nail' }\end{array}$ & osiikta & $\begin{array}{l}\text { *xosii+kta } \\
{ }^{*} \text { xosï+kta }\end{array}$ & $\begin{array}{l}\text { SS 2.26-27 } \\
\text { EEWTD [8995] }\end{array}$ \\
\hline umhan umgan 'eggs' & umuukta & *umuu $+\mathrm{kta}$ & SS 2.269 \\
\hline итри 'cornel' & (Ulcha omakta) & *umV+kta & SS 2.16, 268 \\
\hline usata 'milt, soft roe' & (Negidal oosakta) & *xusa + kta & SS 2.295 \\
\hline
\end{tabular}

The last three items in Table 10 require some elaboration. Manchu usata and Negidal oosakta are false cognates in our framework. We propose that †usaha, from ProtoTungusic *xusa+k.i, has been replaced by newer usata. As for Manchu umpu and umhan (and its variant umgan), they have been the subject of ulterior, sporadic (assimilatory) changes which slightly blur their origin, no matter how evident this may be once internal reconstruction is applied.

As for the remaining words, we propose that Manchu $+h a_{3}$ simply continues $*+\mathrm{k}$. It may be possible that, as in the case of $* \mathrm{~g}$, this formative ${ }^{*}+\mathrm{k}$ had also the paragogic variant $*+k$.i. For this elegant solution to be seriously considered, unfortunately, we lack compelling evidence. The paragogic variant may have been replaced analogically by a new variant with harmonic vocalism. It seems natural to seek for the origin of this analogical replacement in the pluraliser formatives $+t a$ and $+s a$.

To the legitimate question why $*+\mathrm{g}$ did not develop the variant with harmonic vocalism we have the following response: after analogical reanalysis had taken place in pre-Manchuric, $+n g g i$ had little formal resemblance with mono-consonantal domi- 
nant formatives $*+\mathrm{ka}, *+$ ta and $*+\mathrm{sa}$. Additionally, the semantics of plural(iser)s like $*+$ ta and $*+$ sa is closer to that of $*+\mathrm{k}$, since $*+\mathrm{k}$ targets countable nouns, i.e., nouns that can be pluralised.

Conversely, a question could be posed why the remaining formatives did not undergo the analogical reanalysis as in the case of $*+\mathrm{g}$. The only answer we can provide right now is that nasal nouns seem to behave differently when suffixes with initial voiceless consonants are attached to them. Generally speaking, the nasal element of the noun base drops, automatically creating a vowel noun. There is no comparative evidence warranting the reconstruction of nasal nouns with noun class suffix $*+\mathrm{kV}$. This, of course, only describes the facts from the data, rather than explaining them.

\subsection{Some Thoughts on Analogical Reanalysis}

There exists an obvious internal tension in Manchu between nasal and vowel nouns. The mechanism of analogical reanalysis set up above to account for the origin of $+n g g i$ in senggi seems to have taken place in other areas of the Manchu grammar. Interestingly enough, invoking the same mechanism favours either the "suffix solution", whereby nasal nouns are reanalysed as vowel nouns by truncating the final nasal element of the base and attaching it to the (newly created) formative, as in the +nggi examples under discussion, or ningge 'the one which, he who...', or the numeral classifier nofi. The "base solution" is far less common. It implies that the nasal segment in nasal nouns is preserved, the formative being the one to lose substance (see genitive $+i \sim+n i)$.

3.7.1. +ngge and ningge. Hayata (2012; 2015) has recently shown that the origin of the segment $n i$ - in the formation ningge is actually the product of the same reanalysis, that is, at the beginning the last segment of the nasal nouns and the first nasal element of the possessive adjective suffix merged. At some point, a competing form surfaced when the last nasal segment of the nasal noun developed the epenthetic $i$ or, perhaps, as inflected in the genitive case. Be that as it may, ...n+ngge $>\ldots+n g g e$ was progressively replaced with ...n.i+ngge. In a last, dramatic movement, speakers felt that the sequence ...ningge was an autonomous word \#ningge\#.

Table 11. Historical stages leading to the creation of Manchu ningge

\begin{tabular}{lll}
\hline Phase & $\mathrm{V}^{\mathrm{o}}$-noun & $\mathrm{N}^{\mathrm{o}}$-noun \\
\hline 1 & $\mathrm{~V}+$ ngge & $\ldots . n+$ ngge $>\ldots+$ ngge \\
\hline 2 & $\mathrm{~V}+$ ngge & $\ldots$.n+nge $>\ldots+$ ngge \\
& & $\&$ \\
& & $\ldots .$. . + ngge \\
\hline 3 & $\mathrm{~V}+$ ngge & \#ningge \\
\hline
\end{tabular}


3.7.2. nofi. Alonso de la Fuente (2017) has recently argued that the numeral classifier of the sortal type used for human referents nofi 'person (used after numbers higher than one)' might have grown out of sequences like *juwe nan ofi \{two man be-PERFECTIVE CONVERB $\}$ which in course of time were first reduced to *juwenofi (following the model established by numerals where haplology occurred, e.g. *ilan (n)an nofi $>$ *ilananofi $>*$ ilanofi) and later reanalysed as *juwe nofi (in a similar fashion to ningge).

3.7.3. Genitive. As is well known, Manchu genitive $-i$ has a variant $-n i$ that surfaces when the noun base ends in -ng (see, i.a., Gorelova 2002, pp.175-182). The traditional stance regarding the cognacy of the Manchu genitive and the Proto-Tungusic alienable suffix $*+$ nii + is supported, among others, by Benzing (1956, pp. 61-62, $\S 73[\mathrm{f}]$ ) or Menges (see, i.a., 1968, p. 62, where the Ewenki alienable suffix + yii is called "Genitivus", etc., following a tradition that goes back at least to Castrén, see 1856, p. 5, §23). . $^{1}$

Though in theory there is some room for discussion in terms of functional properties, the comparison should be rejected on phonological grounds. For one thing, in order to accept such a comparison, we would have to ignore the fact that in Manchu the loss of *- $n$ - between vowels is irregular. Benzing, like other previous authors, apparently forced the data to match the Manchu case system with that of Core Tungusic, the general assumption being that Manchu has innovated by losing or changing the original system preserved in Core Tungusic (although Benzing's remarks on the instrumental $*+\mathrm{ji}>$ Manchu $+i$ deserve some consideration, cf. archaic collocations of the type ere foni ere fonji 'by those times' in Hauer 2007, p. 160b sub verbo foni \& 161a sub verbo fonji). We believe that the origin of the Manchu genitive has nothing in common with the alienable suffix.

Instead, we find it more promising to seek for the origins of this case ending in the 3SG.POSS marker *-ni, from the oblique of the 3SG personal pronoun, GEN *i.n-i 'his, her' > Manchu ini 'his/her'. Thus, sequences like in-i ama 'his father' developed the positional variant ama in-i (perhaps under Mongolic influence, see, i.a., Poppe 1987, p. 214, although it does not have to be necessarily so), which evolved into ama-ni. The full possessive paradigm arose in Core Tungusic languages after Manchuric branched off. Manchuric retained the incipient 3SG suffix, later the common genitive case, and did not develop the rest of the paradigm, i.e., suffixes for 1 st and

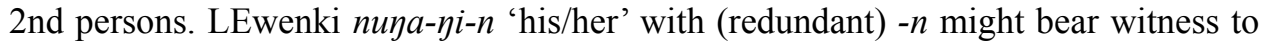
the cyclical nature of the process that led to the full paradigm in Common Tungusic (no redundant endings are present in 1st and 2nd persons' suffixes).

Note that there are remarkable differences in the use of possessives in Manchu and Core Tungusic (see, i.a., Tsumagari 1992, pp. 264-267). The equivalent of LEwenki ura oyo-n \{hill top-3.POSS \} 'the top of the mountain' in Manchu is alin- $i$ ninggu \{mountain-GEN top\} 'the top of the mountain', and Manchu min-i ama 'my

\footnotetext{
${ }^{18}$ Vovin $(2005$, pp. 113, 115) has recently linked Manchu $+i$ with Middle Korean and Old Korean formatives, but without additional evidence, it remains unlikely.
} 
father' corresponds to LEwenki min- $\eta$ i amin-mi 'my father', where min- $\eta i$ is the cognate of Manchu miningge 'mine', though functionally they are not compatible.

The allomorphy of the Manchuric genitive, namely $-i \sim \mathrm{NG}^{\mathrm{o}}-n i$ is an obvious innovation, which can be explained as a morpheme boundary reinterpretation stemming also from the $\mathrm{n}^{\mathrm{o}}$-nouns. It is necessary to bear in mind that Manchuric languages dislike geminates and systematically solve them by simplification (note that this same proportion may have, at a later stage, given rise to the presence of the unstable *.../n):

\section{Table 12. Historical stages leading to the creation of the Manchu genitive allomorphs}

\begin{tabular}{|c|c|c|c|c|c|}
\hline Phase & Case & $\mathrm{V}^{\mathrm{o}}$-noun & & $\mathrm{n}^{\mathrm{o}}$-noun & $\mathrm{y}^{\mathrm{o}}$-noun \\
\hline 1 & $\begin{array}{l}\text { NOM } \\
\text { GEN }\end{array}$ & $\begin{array}{l}\text { abka 'heaven; emperor' } \\
\text { *abka+ni }\end{array}$ & & $\begin{array}{l}\text { aisin 'metal, gold' } \\
\text { *aisin+ni }\end{array}$ & $\begin{array}{l}\text { gurung 'palace' } \\
\text { gurung+ni }\end{array}$ \\
\hline 2 & $\begin{array}{l}\text { NOM } \\
\text { GEN }\end{array}$ & $\begin{array}{l}a b k a \\
a b k a-i\end{array}$ & $F$ & $\begin{array}{l}\text { aisin } \\
\text { aisin-i }\end{array}$ & $\begin{array}{l}\text { gurung } \\
\text { gurung }+n i\end{array}$ \\
\hline
\end{tabular}

The fact that the original $*+$ ni is retained after final $/ \mathrm{y} /$ should come as no surprise. The fail to assimilate in one or the other direction (yielding either *nn or *yy) did not trigger the analogical process which obviously took place in the case $n^{\circ}$-bases.

\section{Conclusion}

Manchu +nggi in senggi 'blood' is not related to +nggi in etenggi 'strong, powerful'. We suggest instead that the former is the product of the analogical reanalysis whereby the nasal segment of nasal nouns is transferred to the suffix noun class suffix $*+\mathrm{g}(. \mathrm{i})$. Jurchen and the majority of Core Tungusic languages preserve the original suffix (as an archaism) more clearly. The new sequence *...n+g.i yields $+n g g i$ which is generalised to vowel nouns where originally there was no nasal element. The very same analogical reanalysis may have operated in the case of nofi and ningge, supporting the idea that there is a sort of conspiracy in order to erase nasal nouns so that vowel nouns can be generalised, which from a morphonological viewpoint seem more transparent for inflectional and derivational processes.

This scenario is far more economical than the received view and it basically accounts for all the internal data. Let us take, for illustrative purposes, the case of Manchu senggi and see it through the framework we have just described above. Manchu senggi 'blood' goes back to Proto-Tungusic *sä(ä)+g and relates to LEwenki sääksä 'id' via Common Tungusic *[sää-k-sä] 'id'. The terms for 'blood' and 'red' are etymologically related (see, i.a., SS 2.136a and 138-139, respectively): Zey Ewenki sägjän, LNanai \& Kili säägjä(n-), Orok säägdä(n-), Ulcha sägjä(n-), Oroch 
sägjä 'bloody-red' < Common Tungusic *säägjän. The segment $-g$ - corresponds to noun class suffix $*+$ g.i. Derivative suffix $*+$ jan is regularly attached to the base

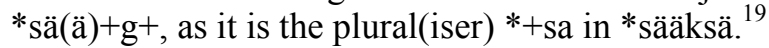

Kolesnikova (1972, pp. 268-269) brings into the picture another set of Tungusic words (Oroch sä̈giki, Negidal \& Ulcha sääygi, Orok säygi 'family; kin, clan', Udihe säygitä 'relatives, kinsfolk', etc.) which show well-known semantic links with 'blood' (cf. Polish krew 'blood' $\rightarrow$ krewny 'relative' = *sää 'blood' $\rightarrow$ *sää+y.i 'relative'). These words contain the alienable suffix *-y.i, to which Mongolic suffix $+k i$ was attached in Oroch, whereas in Udihe we have the pluraliser $+t a$ (inherited or borrowed from Manchuric). Manchu sengge 'elder; old', though similar in shape and meaning, is rather derived from *sää 'year; age' (SS 2.133a, not attested in Northern Tungusic). ${ }^{20}$

The following tree summarises the historical events touched upon in this paper:

\section{Proto-Tungusic}

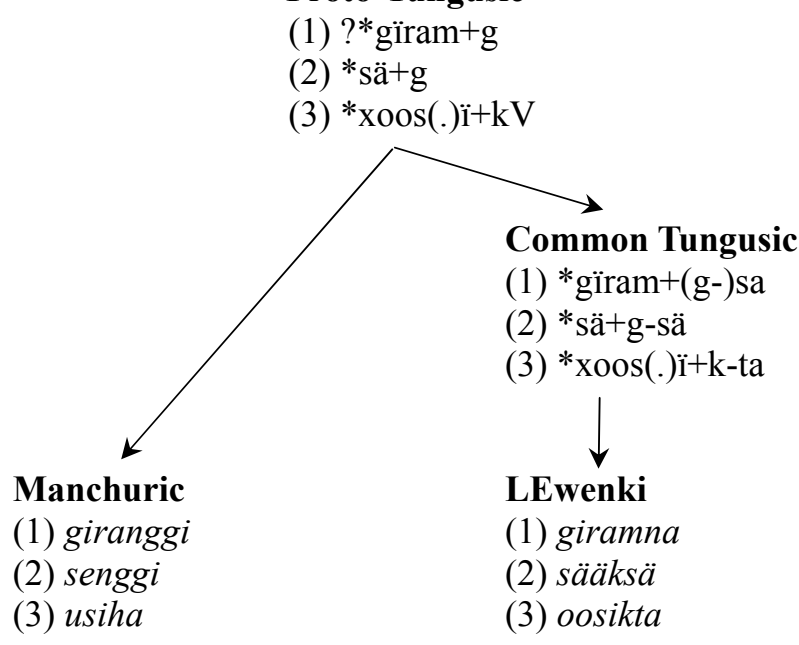

${ }^{19}$ There is no simple solution for the vacillation of vocalic length. In a totally speculative note, we can propose that the original base is *sä, with short vowel, and when followed by one $\left(*_{-}-\mathrm{g}-\right)$ or two $(*$-gj-) voiced consonants, the vowel sporadically lengthens. Long vowel would have been extended to all contexts including non-voiced consonants $(*-\mathrm{ks}-)$.

${ }^{20}$ The external connections of *sä(ä) are a hotly debated issue, though irrelevant for the present purposes. It could be related to Chinese 血 $x u e ̀$ 'blood' (cf. Late Middle Chinese xyat and Early Middle Chinese xwet in Pulleyblank 1991, p. 351; Schuessler 2007, pp. 547-548; Matisoff 2003, p. 194 compares this Chinese word with Proto-Tibeto-Burman *s-hywəy 'blood' > Written Burmese swê, Jingpho sài, Lepcha vi, Garo an-tśi, etc.), but this clearly contradicts the proposal by Cincius and Bugaeva (1979), echoed in Menges (1983, pp. 125-127), according to which *sä-/so-/su-, the meaning of which is 'red, orange-colored, brown', would be the origin not only of the word for 'blood', but also of other words such as *sälä 'iron'. Rybatzki (2002, pp. 113-116) mentions that already Schmidt argued for the Chinese origin of this term (see Schmidt 1933, p. 386b s.v. sele, from tiè 'iron < Late Middle Chinese $t^{h}$ iat and Early Middle Chinese $t^{h} \varepsilon t$ in Pulleyblank 1991, p. 308; Schuessler 2007, p. 497). Curiously enough, Chinese tiě 'iron' is traditionally defined as 'black metal' (such a nuance has been partially preserved in the homonym tiě 'black horse', see Schuessler 2007, p. 497). Although this may have no impact on the etymology of the Tungusic words, it shows that the correspondence red $\leftrightarrow$ iron is not necessarily the only option. 
We take here the opportunity to reproduce again Table 1, but after having applied the pertinent modifications, i.e., we replace Mongolic data with Proto-Tungusic reconstructions, and Common Tungusic (the immediate predecessor of Core Tungusic languages) takes the place of Janhunen's Tungusic.

\section{Table 13. Historical outcome of the Proto-Tungusic noun class suffixes in Manchu and Core Tungusic (via Common Tungusic)}

\begin{tabular}{|c|c|c|c|c|}
\hline Common Tungusic & & Proto-Tungusic & & Manchu \\
\hline *xüy-K.tä & & $*^{x}$ üy $+\mathrm{kV}$ & $>$ & wei-he \\
\hline${ }^{*}$ xoosï-K-ta & & ${ }^{*} \mathrm{xoos}(.) \mathrm{i}+\mathrm{kV}$ & $>$ & usi-ha \\
\hline *usï-K-ta & & ${ }^{*} \mathrm{us}(.) \mathrm{i}+\mathrm{kV}$ & $>$ & wasi-ha \\
\hline 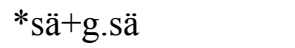 & & $*_{s a ̈+g}$ & $\Rightarrow$ & $s e-n g . g i$ \\
\hline *ximö+g.sä & $\leftarrow$ & ${ }^{*} \mathrm{ximö}+\mathrm{g}$ & $\Rightarrow$ & (n)ime-ng.gi \\
\hline$*_{\text {sile }+ \text { g.sä }}$ & & $*_{\text {silä}+g}$ & $\Rightarrow$ & sile-ng.gi \\
\hline *xïma/n+(g-)sa & & $? * x \ddot{m a} / \mathrm{n}+\mathrm{g}$ & $>$ & nima-ng.gi \\
\hline *gïram+(g-)sa & & ?*gïram+g & $>$ & gira-ng.gi \\
\hline
\end{tabular}

It is unclear whether we have to reconstruct for Common Tungusic either *xïma/n+sa and *gïram + sa, or *xïma/n+g-sa and *gïram + g-sa, or perhaps both variants. We favour the latter option: at some point in the prehistory of Common Tungusic both formations might have been possible. The diversity of historical outcomes is a direct reflect of the existence of these two competing formations. When formative $*+$ sa was attached to nasal nouns with $*+\mathrm{g}$, various strategies were adopted to avoid the threeconsonant cluster, e.g. LNanai germaksa 'bone', from *gïram-g-sa, where metathesis dissolved the resulting cluster. Nasal nouns without $*+\mathrm{g}$ evolved regularly, e.g. *xïma/n+(g-)sa 'snow'> LEwenki imana, Oroch imasa, LNanay semata semana, Solon imanda, etc. (SS 1.312-313).

Needless to say, language-specific internal processes, perhaps similar to those described above for Manchu (existence of competing forms, unclear assignation of available formatives, analogical reanalyses, etc.), may have altered the distribution and final makeup of all words containing noun class suffixes. It is clear that nominal classes are no longer productive in any historical language, be that Manchuric or Core Tungusic. The archaic nature of these formations partly explains the convoluted history of the system (which at some point in the prehistory of the parent language was undoubtedly active) and the many particularities that we have to account for in many individual etymologies. 


\section{References}

Alonso de la Fuente, J. A. (2012): Written Manchu talman 'fog, mist' and the Tungusic liquids. Zentralasiatische Studien Vol. 41, pp. 107-135.

Alonso de la Fuente, J. A. (2013a): Vowel Epenthesis in Orok ulisä 'meat'. Hoppō jinbun kenkyū Vol. 6, pp. 121-127.

Alonso de la Fuente, J. A. (2013b): Written Manchu šumin 'deep'. Rocznik Orientalistyczny Vol. 66, No. 1, pp. $103-113$.

Alonso de la Fuente, J. A. (2017): From Converb to Classifier? On the Etymology of Literary Manchu nofi. In: Németh, M.-Podolak, B.-Urban, M. (eds): Essays in the History of Languages and Linguistics. Dedicated to Marek Stachowski on the Occasion of His 60th Birthday. Kraków, pp. 57-80.

Benzing, J. (1956): Die tungusischen Sprachen. Versuch einer vergleichenden Grammatik. Wiesbaden.

Boldyrev, B. V. (1987): Slovoobrazovanie imen suščestvitel'nyx v tunguso-man'čžurskix jazykax v sravnitel'no-istoričeskom osveščenii. Novosibirsk.

Campbell, L. (2000 [1998]): Historical Linguistics. An Introduction. Cambridge.

Castrén, M. A. (1856): Grundzüge einer tungusischen Sprachlehre nebst kurzem Wörterverzeichniss. St. Petersburg.

Cincius, V. I. (1946): Množestvennoe čislo imeni v tunguso-man'čžurskix jazykax. Učenye zapiski LGU 69 (Serija filologiceskaja, vyp. 10), pp. 73-119.

Cincius, V. I. (1949): Sravnitel'naja fonetika tunguso-man'čžurskix jazykov. Leningrad.

Cincius, V. I. (1977): Mongol'skie affiksy v man'čžurskim jazyke. In: Décsy, Gy.-Dimov-Bogoev, Ch. D. (eds): Eurasia Nostratica. Festschrift für K.H. Menges. Wiesbaden, Vol. 1, pp. $42-48$.

Cincius, V. I. - Bugaeva, T. G. (1979): K ètimologii nazvanij metallov i ix splavov v altajskix jazykax. Issledovanija v oblasti ètimologii altajskix jazykov. Leningrad, pp. 18-52.

Corbett, G. (2007): Gender and noun Classes. In: Shopen, T. (ed.): Language Typology and Syntactic Description, Vol. III: Grammatical Categories and the Lexicon. Cambridge, pp. 241279.

Corff (2013) = Corff, O. - Maezono, K. - Lipp, W. - Droj, D. - Gerelmaa, G. - Mirsultan, A. - Stüber, R. - Töwshintögs, B. - Li, X. (2013): Auf kaiserlichen Befehl erstelltes Wörterbuch des Manjurischen in fünf Sprachen, 2 vols ( 5 vols for the indices). Wiesbaden.

Crowley, T. (1994 [1992]): An Introduction to Historical Linguistics (Second Edition). Oxford.

Doerfer, G. (1978): Urtungusische *ö. In: Weiers, M. (ed.): Tungusica. Beiträge zur nordasiatischen Kulturgeschichte. Wiesbaden, pp. 66-116.

EEWTD = Doerfer, G. (2004): Etymologisch-ethnologisches Wörterbuch tungusischer Dialekte (vornehmlich der Mandschurei). Unter Mitwirkung von Michael Knüppel. Hildesheim-Zürich-New York.

Gorelova, L. M. (2002): Manchu Grammar. Leiden.

Grenoble, L. A. - Whaley, L. J. (2003): The Case for Dialect Continua in Tungusic. Plural Morphology. In: Holisky, D. A.-Tuite, K. (eds): Current Trends in Caucasian, East European and Inner Asian Linguistics. Papers in Honor of Howard I. Aronson. Amsterdam, pp. $97-$ 120.

Hauer, E. (2007 [1952-1955]): Handwörterbuch der Mandschusprache. Wiesbaden.

Hayata Teruhiro (2012): Manshū-go no n Ø kōtai no shiteki gaikan. Altai hakpo Vol. 22, pp. $93-$ 110. 
Hayata Teruhiro (2015): Manshū-go no tayō na keitaiso -ngge no bunpōteki ichizuke. Gengo kenky $\bar{u}$ Vol. 148, pp. 33-60.

Hock, H. H. (1991 [1986]): Principles of Historical Linguistics (Second revised and updated version). Berlin and New York.

Hock, H. H.-Joseph, B. D. (2009 [1996]): Language History, Language Change, and Language Relationship. An Introduction to Historical and Comparative Linguistics (Second revised edition). Berlin-New York.

Janhunen, J. (1996): Prolegomena to a Comparative Analysis of Mongolic and Tungusic. In: Stary, G. (ed.): Proceedings of the 38th Permanent International Altaistic Conference (PIAC, Kawasaki, Japan: August 7-12, 1995). Wiesbaden, pp. 209-218.

Janhunen, J. (1999): Grammatical Gender from East to West. In: Unterbeck B. - Rissanen M. (eds): Gender in Grammar and Cognition. Berlin-New York, pp. 689-707.

Jīn Qǐcóng (1984): Nǚzhēn wén cídiăn. Běijīng.

Kane, D. (1989): The Sino-Jurchen Vocabulary of the Bureau of Interpreters. Bloomington.

Kazama, Sh. (2003): Basic Vocabulary (A) of Tungusic Languages. Suita.

Kim (2008) = Kim, J. - Ko, D. - Chaoke, D. O. - Han, Y. - Piao, L. - Boldyrev, B. V. (2008): Materials of Spoken Manchu. Seoul.

Kiyose, G. (1977): A Study of the Jurchen Language and Script. Kyoto.

Kolesnikova, V. D. (1972): K xarakteristike nazvanij častej tela čeloveka v tunguso-man'čžurskix jazykax. In: Cincius, V. I. (ed.): Očerki sravnitel'noj leksikologii altajskix jazykov. Leningrad, pp. 257-336.

Matisoff, J.A. (2003): Handbook of Proto-Tibeto-Burman. System and Philosophy of Sino-Tibetan Reconstruction. Berkeley-Los Angeles-London.

Menges (1968) = Fuchs, W. - Lopatin, I. A. - Menges, K. H. - Sinor, D. (1968): Tungusologie. Leiden-Köln.

Menges, K. (1978): Problems of Tungus linguistics. Anthropos Vol. 73, pp. 367-400.

Menges, K. (1983): Etymologika zu den altajischen Bezeichnungen von Metallen, Haustieren und Gewächsen. Ural-Altaische Jahrbücher (NF) Vol. 3, pp. 102-165.

Millar, R. M. (ed.) (2015 [1996]): Trask's Historical Linguistics (Third edition). London-New York.

Miller, D. Gary (2010): Language Change and Linguistic Theory I. Approaches, Methodology, and Sound Change. Oxford.

Miller, R. A. (1994): The Original Geographic Distribution of the Tungus Languages. In: Aronson, H. I. (ed.): Non-Slavic Languages of the USSR. Papers from the Fourth Conference. Columbus, pp. 272-297.

Näher, C. (1988): Der urtungusische stimmlose velare Plosiv im Mandschu. Journal de la Société Finno-Ougrienne Vol. 88, pp. 113-130.

Pevnov, A. M. (2005): Ob otličijax čžurčžèn'skogo pis'ma ot kitajskogo, a takže čžurčžèn'skogo jazyka ot man'čžurskogo. Rocznik Orientalistyczny (Opera altaistica professori Stanislao Katużyński octogenario dicata) Vol. 58, No. 1, pp. 133-140.

Poppe, N. (1987 [1955]): Introduction to Mongolian Comparative Studies. Helsinki.

Pulleyblank, E. G. (1991): Lexicon of Reconstructed Pronunciation in Early Middle Chinese, Late Middle Chinese, and Early Mandarin. Vancouver.

Ramstedt, G. J. (1952): Einführung in die altaische Sprachwissenschaft (ed. Pentti Aalto). Vol. 2: Formenlehre. Helsinki.

Rozycki, W. (1994): Mongol Elements in Manchu. Bloomington.

Rybatzki, V. (2002): Die tungusische Metallterminologie. Studia Etymologica Cracoviensia Vol. 7 , pp. $89-126$. 
Schmidt, P. (1933): Chinesische Elemente im Mandschu III. Asia Major Vol. 8, pp. 353-436.

Schuessler, A. (2007): ABC Etymological Dictionary of Old Chinese. Honolulu.

SS = Cincius, V. I. (ed.) (1975-1977): Sravnitel'nyj slovar' tunguso-man 'čžurskix jazykov, 2 vols. Leningrad.

Sunik, O. P. (1982): Suščestvitel'noe v tunguso-man'čžurskix jazykax. V sravnenii s drugimi altajskimi jazykami. Leningrad.

Tsumagari, T. (1992): Shoyū-kōzō jo jōtokanōsei: tsungūsu go to kinrin no gengo. In: Miyaoka, O. (ed.): Kita no gengo. Ruikei to rekishi. Tōkyō, pp. 261-278.

Tsumagari, T. (1997): Linguistic Diversity and National Borders of Tungusic. Senri Ethnological Studies (Northern Minority Languages: Problems of Survival) Vol. 44, pp. 175-186.

Vietze, H.-P. (1969): Plural, Dual und Nominalklassen in altaischen Sprachen. Wissenschaftliche Zeitschrift der Humboldt-Universität zu Berlin. Gesellschafts-Sprachwissenschaftliche Reihe Vol. 18, No. 3, pp. 481-512.

Vovin, A. (2005): Koguryŏ and Paekche: Different Languages or Dialects of Old Korean? Journal of Inner and East Asian Studies Vol. 2, No. 2, pp. 108-140. 